\title{
BEJANA UKUR STANDAR DENGAN TAMPILAN DIGITAL MENGGUNAKAN SENSOR KAPASITIF BERBASIS ARDUINO NANO
}

\author{
Mas Ninda Pertiwi \\ Fakultas Sekolah Vokasi, Program Studi Metrologi dan Instrumentasi \\ Departemen Teknik Elektro dan Informatika \\ Universitas Gadjah Mada \\ Email: mas.ninda.pertiwi@mail.ugm.ac.id \\ Galih Setyawan \\ Fakultas Sekolah Vokasi, Program Studi Metrologi dan Instrumentasi \\ Departemen Teknik Elektro dan Informatika \\ Universitas Gadjah Mada \\ Email: galih.setyawan@mail.ugm.ac.id
}

\begin{abstract}
ABSTRAK
Pada saat ini, bejana ukur standar hanya terdapat model manual, yakni dengan menggunakan jangka sorong. Namun, salah satu kekurangannya disebabkan oleh human error. Oleh karena itu, dilakukan penelitian membuat bejana ukur standar dengan tampilan digital. Tujuan dari penelitian ini adalah untuk mengetahui cara kerja sensor kapasitif dalam mendeteksi volume cairan, hasil pengujian volume terukur pada media air keran, dan konsistensi alat dalam membaca volume terukur pada media cairan yang berbeda. Pengujian dilakukan dengan menggunakan air keran dan air sirup dengan dua analisis pengujian, yakni berdasarkan nilai modus datalog dan LCD sebagai pembandingnya. Pengambilan data dilakukan setiap $50 \mathrm{~mL}$ pada rentang $9700 \mathrm{~mL}$ hingga 10300mL. Berdasarkan hasil pengujian, diketahui bahwa sensor kapasitif bekerja dengan baik mendeteksi nilai volume cairan. Pada air keran, volume terukur berdasarkan nilai modus pada datalog memiliki linearitas 0,9992 dan rata-rata selisih terbesar $21 \mathrm{~mL}$. Sedangkan berdasarkan nilai modus pada LCD, linearitas yang dimiliki sebesar 0,9991 dan rata-rata selisih terbesar adalah $22 \mathrm{~mL}$. Pada media cairan berbeda (air sirup), nilai volume terukur lebih kecil dibandingkan air keran, dikarenakan konstanta dielektrik air sirup lebih kecil dibandingkan air keran.
\end{abstract}

Kata kunci: bejana ukur, kapasitif, arduino nano

\begin{abstract}
Commonly, there is only manual standard measuring vessel which is use caliper. However, the use of calipers can cause human error. Therefore, research was conducted to make standard measuring vessel with digital display. The purposes of this research were to know the working of capacitive sensor in detecting liquid volume, the results of volume testing on water as media, and consistency in reading measured volumes on different liquid media. Tests were carried out using tap water and syrup water with two test analyzes, namely based on the datalog mode and LCD values as a comparison. Data was collected every $50 \mathrm{~mL}$ in the range of $9700 \mathrm{~mL}$ to $10300 \mathrm{~mL}$. Based on the test results, it was known that the capacitive sensor can work by detecting liquid volume value. On tap water, the measured volume test results with the modus value on the datalog had linearity of 0,9992 and the largest average difference was $21 \mathrm{~mL}$. In different liquid media (syrup water), the measured volume value is smaller than tap water, because the dielectric constant of syrup water is smaller than tap water.
\end{abstract}

Keywords: measuring vessel, capacitive, arduino nano 


\section{PENDAHULUAN}

Semakin berkembangnya zaman, Ilmu Pengetahuan dan Teknologi (IPTEK) semakin berkembang pula disertai dengan berkembangnya instrumen dan alat pendukung pada kehidupan sehari-hari. Saat ini, instrumentasi yang pada awalnya dominan berbasis analog kini telah berubah menjadi instrumentasi berbasis digital. Tentunya perubahan instrumen berbasis analog ke digital tersebut memudahkan penggunanya. Selain dari sisi fungsi membuat instrumen tersebut menjadi mudah dalam penggunaannya, instrumen yang berbasis digital dapat meminimalisir hingga menghilangkan tingkat kesalahan terutama akibat perbedaan pembacaan pengguna atau human error.

Salah satu instrumen yang berkaitan dalam dunia metrologi legal adalah bejana ukur. Bejana ukur adalah alat ukur volume yang berfungsi sebagai alat ukur standar bagi alat ukur volume lainnya dan termasuk dalam alat Ukur, Takar, Timbang, dan Perlengkapannya (UTTP) yang wajib ditera dan ditera ulang [1]. Saat ini, bejana ukur masih berbasis analog dengan menggunakan jangka sorong sebagai media pengukuran untuk membaca nilai volume dari kapasitas bejana ukur tersebut. Pembacaan berbasis analog tersebut memiliki kemungkinan besar dalam pembacaan nilai kesalahan, terlebih pada faktor human error. Pada kesalahan dikarenakan human error, hasil pembacaan nilai volume bejana ukur dapat terbaca beda oleh orang yang berbeda. Oleh karena itu, untuk menghilangkan kesalahan pada faktor human error maka dibuat bejana ukur standar dengan tampilan digital. Selain berfungsi menampilkan volume dengan tampilan digital, alat yang dibuat dilengkapi dengan fitur kalibrasi volume dan fitur menyimpan hasil pengukuran ke database. Tujuan dari penelitian ini adalah untuk mengetahui cara kerja sensor kapasitif dalam mendeteksi volume cairan, hasil pengujian volume terukur pada media air keran, dan konsistensi alat dalam membaca volume terukur pada media cairan yang berbeda.

\section{METODOLOGI PENELITIAN}

Penelitian yang dilakukan merupakan penelitian tahap awal dikarenakan sebelumnya belum ada penelitian yang membuat bejana ukur standar dengan tampilan digital. Adapun tahap pembuatan bejana ukur standar dengan tampilan digital adalah penentuan alat dan bahan yang digunakan dalam penyusunan rangkaian sistem, kemudian penentuan diagram alir sistem saat beroperasi, dan rancangan perangkat keras sistem. Rincian dari masing-masing tahap tersebut adalah sebagai berikut.

\subsection{Alat dan Bahan}

Alat dan bahan yang digunakan adalah bejana ukur 10L, LCD 20x4 I2C, Arduino Nano, tembaga foil tape, push button, modul sensor kapasitif kelembaban tanah V1.2, gelas takar $2 \mathrm{~L}$ merek GreanLeaf, gelas ukur 50mL merek Pyrex, air keran, sirup merek Marjan Cocopandan 920 mL, modul kartu MircroSD, dan RTC DS3231.

\subsection{Blok Diagram}

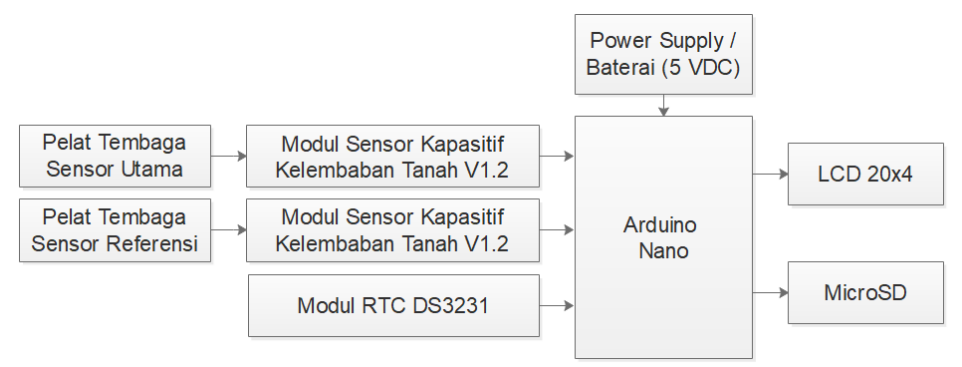

Gambar 1. Blok Diagram Bejana Ukur Standar dengan Tampilan Digital 
Blok diagram dari bejana ukur standar dengan tampilan digital tertera pada Gambar 1. Berdasarkan blok diagram tersebut, dapat diketahui bahwa power supply yang digunakan dalam pengoperasian bejana ukur standar dengan tampilan digital adalah baterai. Plat tembaga digunakan sebagai pengukur volume untuk menggantikan jangka sorong yang terdapat pada bejana ukur standar dengan tampilan manual. Mikrokontroler Arduino Nano digunakan sebagai pusat pengolahan data yang terintegrasi dengan komponen-komponen lainnya. Database yang digunakan dalam alat ini adalah modul kartu microSD. Interface yang digunakan dalam sistem ini adalah LCD 20x4. Selain itu, digunakan juga modul RTC DS3231 sebagai penampil waktu dalam sistem bejana ukur standar dengan tampilan digital agar dapat menampilkan waktu secara real time.

\subsection{Diagram Alir}

Adapun alur kerja sistem yakni sebagaimana tercantum pada Gambar 2 di bawah ini.

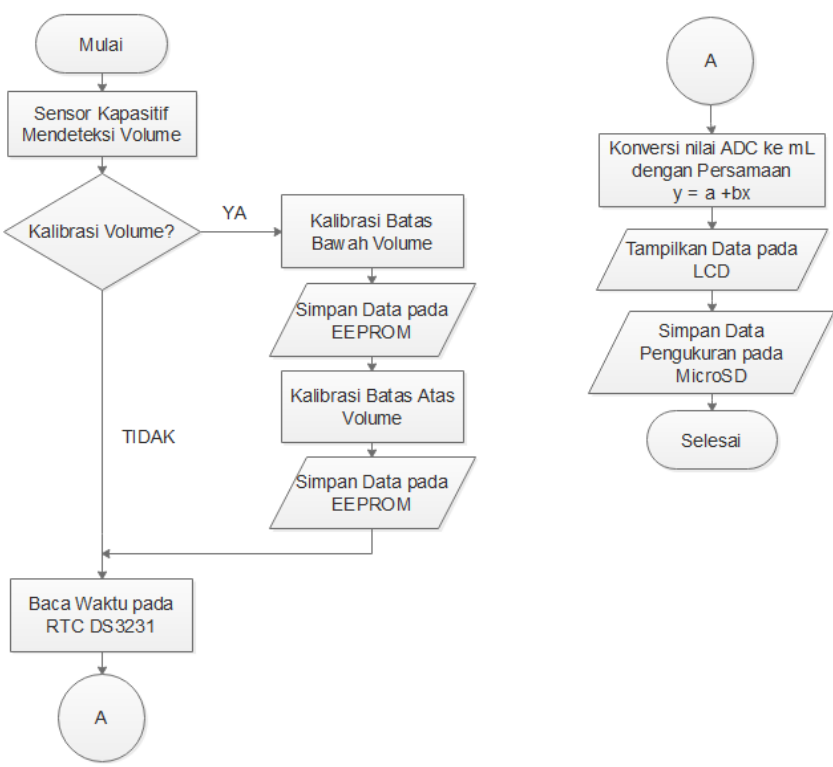

\section{Gambar 2. Diagram Alir Sistem Kerja Bejana Ukur Standar dengan Tampilan Digital}

Gambar 2 merupakan diagram alir sistem saat bejana ukur standar dengan tampilan digital ketika dioperasikan. Pada bejana ukur standar dengan tampilan digital terdapat menu kalibrasi yang dapat dipilih user sebelum mengukur volume pada bejana ukur. Dalam kalibrasi volume, terbagi atas dua tahap, yakni kalibrasi batas bawah volume kemudian dilanjutkan dengan kalibrasi batas atas volume. Kalibrasi batas bawah setara dengan $9700 \mathrm{~mL}$ yang mana merupakan nilai dari rentang terendah yang dapat terbaca oleh alat, sedangkan kalibrasi batas atas setara dengan 10300 $\mathrm{mL}$ yang merupakan nilai dari rentang tertinggi yang dapat terbaca oleh alat. Nilai ADC hasil dari kalibrasi batas bawah dan batas atas volume akan disimpan pada memori EEPROM Arduino Nano. Nilai ADC tersebut akan dikonversikan ke dalam satuan $\mathrm{mL}$ menggunakan persamaan regresi, yakni pada Persamaan 1.

$y=a+b x$

Persamaan 1 yang telah diperoleh dari hasil kalibrasi kemudian digunakan untuk mengkonversi hasil volume yang terukur oleh sensor dari nilai ADC menjadi satuan mL. Nilai volume dengan satuan $\mathrm{mL}$ akan ditampilkan pada LCD. Pada bejana ukur standar dengan tampilan 
digital dilengkapi RTC DS3231 untuk menampilkan waktu secara real time dan dilengkapi fitur datalog pada microSD. Data hasil pengukuran baik pengujian ataupun pengkalibrasian dapat disimpan pada kartu microSD dengan pencatatan waktu real time pada saat pengukuran.

\subsection{Rancangan Perangkat Keras Sistem}

Desain perangkat keras dari bejana ukur standar dengan tampilan digital ini tertera pada Gambar 3.

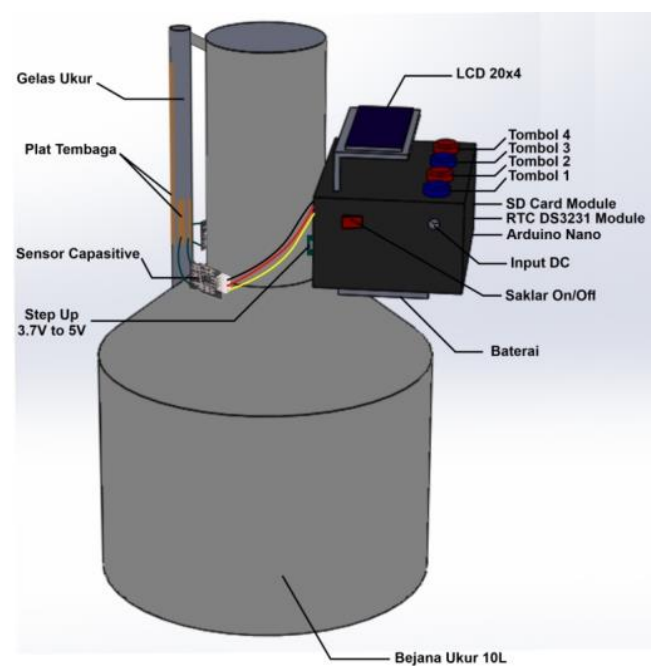

\section{Gambar 3. Desain Perangkat Keras Bejana Ukur Standar dengan Tampilan Digital}

Gambar 3 menunjukkan desain perangkat keras dari bejana ukur standar dengan tampilan digital yang tersusun dari komponen-komponen yang tertera pada gambar di atas. Masing-masing komponen tersebut saling terintegrasi sehingga bejana ukur standar dengan tampilan digital dapat beroperasi sesuai perintah user. Perbedaan signifikan antara bejana ukur standar yang digunakan secara manual dengan bejana ukur standar dengan tampilan digital adalah pengukur volumenya. Pada bejana ukur standar yang digunakan secara manual, terdapat jangka sorong yang berfungsi untuk mengukur volume cairan secara manual pada gelas ukur, namun pada bejana ukur digital ini, jangka sorong tersebut digantikan dengan dua pasang pelat tembaga.

\section{HASIL DAN PEMBAHASAN}

Bejana ukur standar dengan tampilan digital ini merupakan pengembangan dari bejana ukur standar manual, yang mana rentang pengukuran volume tersebut adalah sama, yakni dari $9700 \mathrm{~mL}$ hingga 10300mL. Pengujian dilakukan dengan menggunakan dua jenis cairan, yakni air keran dan air sirup serta dua alat ukur volume sebagai standar. Pada masing-masing jenis cairan dilakukan dua analisis volume terukur, yakni volume berdasarkan nilai modus pada datalog sebagai utamanya dan nilai modus pada LCD sebagai pembanding. Dua alat ukur yang digunakan sebagai standar adalah gelas takar Greenleaf berkapasitas 2L dan gelas ukur Pyrex berkapasitas 50mL. Gelas takar 2L digunakan untuk mengisi cairan pada bejana dengan rentang $0 \mathrm{~mL}$ hingga 9700 $\mathrm{mL}$, sedangkan gelas ukur $50 \mathrm{~mL}$ digunakan untuk mengisi cairan pada bejana dengan rentang $9700 \mathrm{~mL}$ hingga $10300 \mathrm{~mL}$. Sebelum dilakukan pengujian volume, alat terlebih dahulu dikalibrasi. Persamaan regresi hasil kalibrasi alat tertera pada Persamaan 2.

$y=-5937,7 x+14745$ 
Persamaan 2 digunakan untuk mengkonversi volume dari nilai ADC menjadi satuan $\mathrm{mL}$. Setelah dilakukan kalibrasi volume, selanjutnya dilakukan pengujian volume pada media air keran. Analisis pertama adalah volume terukur berdasarkan nilai modus pada datalog. Adapun hasil analisis tertera pada Tabel 1 .

Tabel 1. Data Hasil Pengujian Volume Berdasarkan Nilai Modus pada Datalog untuk Media Air Keran

\begin{tabular}{cccccccc}
\hline \multirow{2}{*}{$\begin{array}{c}\text { Standar } \\
(\mathbf{m L})\end{array}$} & I & II & III & $\begin{array}{c}\text { Selisih } \\
(\mathbf{m L})\end{array}$ & $\begin{array}{c}\text { Nilai } \\
\text { ADC }\end{array}$ & $\begin{array}{c}\text { Volume } \\
\text { terukur } \\
(\mathbf{m L})\end{array}$ & $\begin{array}{c}\text { Standar } \\
\text { deviasi } \\
(\mathbf{m L})\end{array}$ \\
\hline 9700 & 17 & 7 & 7 & 10 & 0,84796 & 9710 & 5 \\
\hline 9750 & 28 & 18 & 18 & 21 & 0,83764 & 9771 & 5 \\
\hline 9800 & 21 & 11 & 11 & 14 & 0,83046 & 9814 & 5 \\
\hline 9850 & 14 & 14 & 12 & 13 & 0,82221 & 9863 & 1 \\
\hline 9900 & 25 & 15 & 15 & 18 & 0,81290 & 9918 & 5 \\
\hline 9950 & 18 & 18 & 8 & 15 & 0,80507 & 9965 & 5 \\
\hline 10000 & 11 & 11 & 1 & 8 & 0,79780 & 10008 & 5 \\
\hline 10050 & 13 & 13 & 3 & 10 & 0,78914 & 10060 & 5 \\
\hline 10100 & 6 & 6 & -4 & 3 & 0,78183 & 10103 & 5 \\
\hline 10150 & 8 & 8 & 8 & 8 & 0,77257 & 10158 & 0 \\
\hline 10200 & -9 & -9 & -9 & -9 & 0,76696 & 10191 & 0 \\
\hline 10250 & -7 & -7 & -7 & -7 & 0,75826 & 10243 & 0 \\
\hline 10300 & -6 & -6 & -6 & -6 & 0,74957 & 10294 & 0 \\
\hline
\end{tabular}

Setelah diperoleh nilai rata-rata volume terukur sesuai yang tertera pada Tabel 1, selanjutnya nilai rata-rata tersebut dimuat dalam bentuk grafik guna mempermudah dalam menganalisis dan guna mengetahui nilai linearitas yang dihasilkan. Grafik tersebut tertera pada Gambar 4.

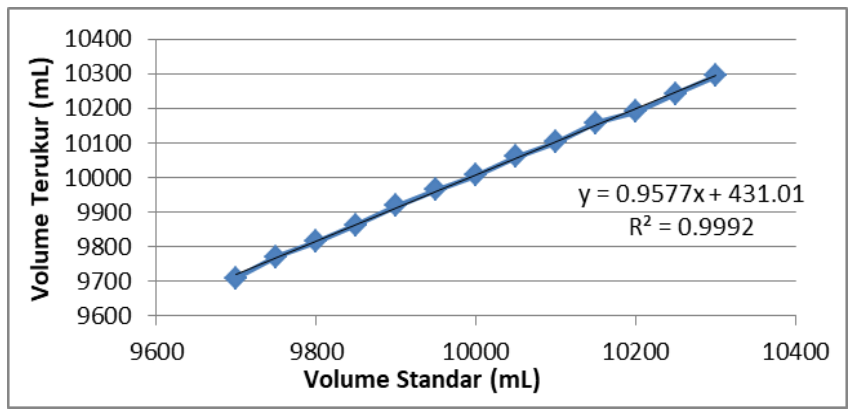

\section{Gambar 4. Grafik Linearitas Hubungan Antara Volume Terukur Berdasarkan Nilai Modus pada Datalog dengan Volume Standar pada Air Keran}

Berdasarkan Gambar 4, diketahui nilai linearitas atau koefisien determinasi yang dihasilkan adalah $\mathbf{R}^{2}=0,9992$. Sehingga diketahui bahwa pengaruh volume terukur terhadap volume standar adalah sebesar $99,92 \%$, sedangkan sisanya dipengaruhi oleh faktor lain. Semakin nilai $\mathrm{R}^{2}$ yang dihasilkan mendekati 1, maka pengaruh antara volume terukur dengan volume standar semakin dekat dan linearitasnya semakin baik. 
Selanjutnya dilakukan analisis data hasil pengujian volume terukur yang diperoleh berdasarkan modus pada LCD dengan media cairan yang sama, yakni media air keran. Analisis dengan mengambil nilai volume berdasarkan nilai modus pada LCD ini bertujuan untuk membandingkan nilai modus volume terukur pada datalog dengan nilai modus volume terukur yang tertampil pada LCD. Adapun data hasil analisis tertera pada Tabel 2.

Tabel 2. Data Hasil Analisis Volume Terukur Berdasarkan Nilai Modus pada LCD untuk Media Air Keran

\begin{tabular}{cccccccc}
\hline \multirow{2}{*}{$\begin{array}{c}\text { Standar } \\
(\mathbf{m L})\end{array}$} & I & II & III & $\begin{array}{c}\text { Selisih } \\
(\mathbf{m L})\end{array}$ & $\begin{array}{c}\text { Nilai } \\
\text { ADC }\end{array}$ & $\begin{array}{c}\text { Volume } \\
\text { terukur } \\
(\mathbf{m L})\end{array}$ & $\begin{array}{c}\text { Standar } \\
\text { deviasi } \\
(\mathbf{m L})\end{array}$ \\
\hline 9700 & 17 & 7 & 7 & 10 & 0,84796 & 9710 & 5 \\
\hline 9750 & 18 & 18 & 18 & 18 & 0,83821 & 9768 & 0 \\
\hline 9800 & 21 & 21 & 11 & 18 & 0,82989 & 9818 & 5 \\
\hline 9850 & 14 & 14 & 12 & 13 & 0,82221 & 9863 & 1 \\
\hline 9900 & 25 & 25 & 15 & 22 & 0,81232 & 9922 & 5 \\
\hline 9950 & 18 & 18 & 8 & 15 & 0,80507 & 9965 & 5 \\
\hline 10000 & 11 & 11 & 1 & 8 & 0,79780 & 10008 & 5 \\
\hline 10050 & 13 & 13 & 3 & 10 & 0,78914 & 10060 & 5 \\
\hline 10100 & 6 & 6 & -4 & 3 & 0,78183 & 10103 & 5 \\
\hline 10150 & 8 & 8 & 8 & 8 & 0,77257 & 10158 & 0 \\
\hline 10200 & -9 & -9 & -9 & -9 & 0,76696 & 10191 & 0 \\
\hline 10250 & -7 & -7 & -7 & -7 & 0,75826 & 10243 & 0 \\
\hline 10300 & -6 & -6 & -6 & -6 & 0,74957 & 10294 & 0 \\
\hline
\end{tabular}

Berdasarkan Tabel 2, jika dibandingkan dengan data hasil analisis volume terukur sebelumnya, dapat diketahui bahwa nilai rata-rata selisih terbesar yang dihasilkan pada analisis ini memiliki selisih $1 \mathrm{~mL}$ lebih besar dibandingkan pada analisis sebelumnya. Rata-rata volume terukur yang dihasilkan kemudian dimuat dalam grafik yang tertera pada Gambar 5 .

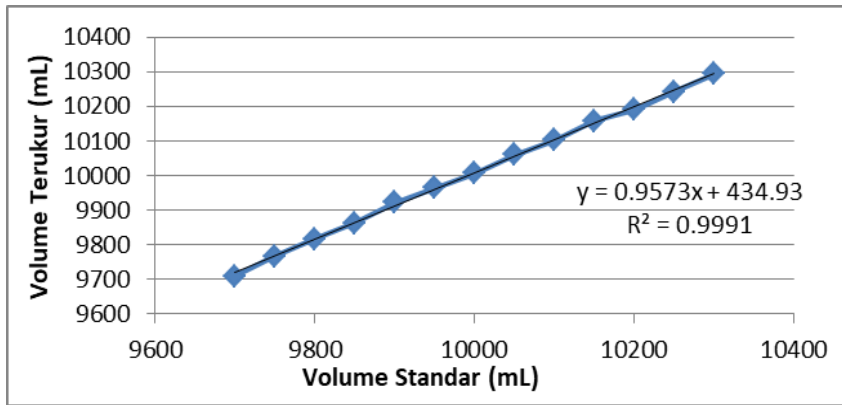

\section{Gambar 5. Grafik Linearitas Hubungan Antara Volume Terukur Berdasarkan Nilai Modus pada LCD dengan Volume Standar pada Air Keran}

Berdasarkan Gambar 5, diketahui bahwa nilai linearitas yang dihasilkan adalah $\mathrm{R}^{2}=0,9991$, nilai ini lebih kecil 0,0001 dibandingkan analisis pengujian sebelumnya. Sehingga diketahui bahwa untuk analisis ini, pengaruh volume standar dengan volume terukur adalah $99,91 \%$. 
Pengujian selanjutnya adalah pengujian volume pada media air sirup. Hasil analisis volume terukur berdasarkan nilai modus pada datalog tertera pada Tabel 3.

Tabel 3. Data Hasil Analisis Volume Terukur Berdasarkan Nilai Modus pada Datalog untuk Media Air Sirup

\begin{tabular}{|c|c|c|c|c|c|c|c|}
\hline \multirow[b]{2}{*}{$\begin{array}{l}\text { Standar } \\
(\mathbf{m L})\end{array}$} & \multicolumn{3}{|c|}{ Selisih (mL) } & \multicolumn{3}{|c|}{ Rata-rata } & \multirow[b]{2}{*}{$\begin{array}{c}\text { Standar } \\
\text { deviasi } \\
(\mathrm{mL})\end{array}$} \\
\hline & $\mathbf{I}$ & II & III & $\begin{array}{c}\text { Selisih } \\
(\mathbf{m L})\end{array}$ & $\begin{array}{l}\text { Nilai } \\
\text { ADC }\end{array}$ & $\begin{array}{c}\text { Volume } \\
\text { terukur } \\
(\mathrm{mL})\end{array}$ & \\
\hline 9700 & 5 & 5 & 0 & 3 & 0,84937 & 9703 & 2 \\
\hline 9750 & 6 & 6 & 6 & 6 & 0,84021 & 9756 & 0 \\
\hline 9800 & 9 & -1 & -1 & 2 & 0,83247 & 9802 & 5 \\
\hline 9850 & 2 & 2 & 0 & 1 & 0,82424 & 9851 & 1 \\
\hline 9900 & 5 & -6 & -7 & -3 & 0,81646 & 9897 & 5 \\
\hline 9950 & -2 & -4 & -4 & -3 & 0,80818 & 9947 & 1 \\
\hline 10000 & -1 & -11 & -13 & -8 & 0,80058 & 9992 & 5 \\
\hline 10050 & -8 & -10 & -10 & -9 & 0,79227 & 10041 & 1 \\
\hline 10100 & -6 & -6 & -9 & -7 & 0,78349 & 10093 & 1 \\
\hline 10150 & -3 & -3 & -5 & -4 & 0,77444 & 10146 & 1 \\
\hline 10200 & -11 & -11 & -11 & -11 & 0,76736 & 10189 & 0 \\
\hline 10250 & -20 & -20 & -20 & -20 & 0,76042 & 10230 & 0 \\
\hline 10300 & -29 & -29 & -29 & -29 & 0,75347 & 10271 & 0 \\
\hline
\end{tabular}

Berdasarkan data analisis yang tercantum pada Tabel 3, dapat diketahui bahwa nilai rata-rata volume terukur pada pengujian menggunakan media air sirup memiliki nilai lebih mendekati volume standar meskipun nilai volume terukur yang dihasilkan dominan memiliki nilai yang lebih kecil dengan volume standar dan volume terukur dengan media air keran. Adapun grafik yang dihasilkan dari data analisis Tabel 3 dimuat pada Gambar 6.

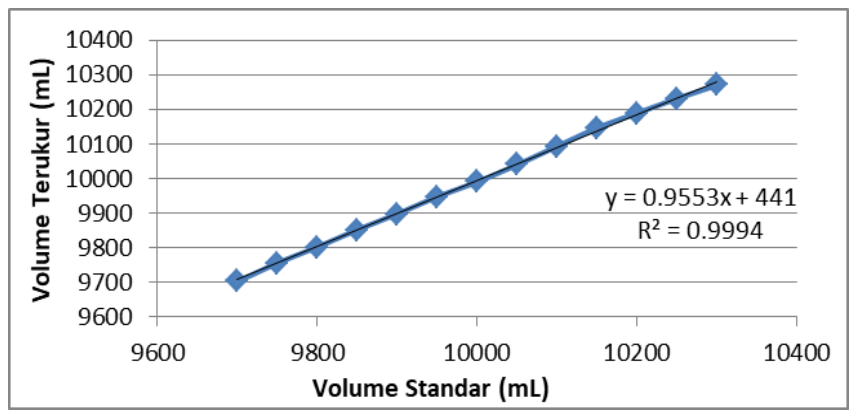

Gambar 6. Grafik Linearitas Hubungan Antara Volume Terukur Berdasarkan Nilai Modus pada Datalog dengan Volume Standar pada Air Sirup

Berdasarkan Gambar 6, dapat diketahui bahwa nilai koefisien determinasi yang dihasilkan adalah 0,9994. Nilai koefisien determinasi ini lebih besar 0,0002 dibandingkan pada pengujian menggunakan media air keran dengan jenis analisis yang sama, yakni analisis volume terukur yang ditentukan berdasarkan nilai modus pada datalog.

Selanjutnya, dilakukan analisis volume terukur berdasarkan nilai modus pada LCD dengan hasil tertera pada Tabel 4. 
Tabel 4. Data Hasil Analisis Volume Terukur Berdasarkan Nilai Modus pada LCD untuk Media Air Sirup

\begin{tabular}{|c|c|c|c|c|c|c|c|}
\hline \multirow[b]{2}{*}{$\begin{array}{c}\text { Standar } \\
(\mathbf{m L} \mathbf{L})\end{array}$} & \multicolumn{3}{|c|}{ Selisih (mL) } & \multicolumn{3}{|c|}{ Rata-rata } & \multirow[b]{2}{*}{$\begin{array}{c}\text { Standar } \\
\text { deviasi } \\
(\mathrm{mL})\end{array}$} \\
\hline & $\mathbf{I}$ & II & III & $\begin{array}{c}\text { Selisih } \\
(\mathrm{mL})\end{array}$ & $\begin{array}{l}\text { Nilai } \\
\text { ADC }\end{array}$ & $\begin{array}{c}\text { Volume } \\
\text { terukur } \\
(\mathbf{m L})\end{array}$ & \\
\hline 9700 & 5 & 5 & 0 & 3 & 0,84928 & 9703 & 2 \\
\hline 9750 & 6 & 6 & 6 & 6 & 0,84021 & 9756 & 0 \\
\hline 9800 & 9 & -1 & -1 & 2 & 0,83247 & 9802 & 5 \\
\hline 9850 & 2 & 2 & 0 & 1 & 0,82424 & 9851 & 1 \\
\hline 9900 & 5 & -6 & -7 & -3 & 0,81646 & 9897 & 5 \\
\hline 9950 & -2 & -4 & -15 & -7 & 0,80876 & 9943 & 6 \\
\hline 10000 & -1 & -11 & -13 & -8 & 0,80058 & 9992 & 5 \\
\hline 10050 & -8 & -10 & -10 & -9 & 0,79227 & 10041 & 1 \\
\hline 10100 & -6 & -6 & -9 & -7 & 0,78349 & 10093 & 1 \\
\hline 10150 & -3 & -3 & -5 & -4 & 0,77444 & 10146 & 1 \\
\hline 10200 & -11 & -11 & -11 & -11 & 0,76736 & 10189 & 0 \\
\hline 10250 & -20 & -20 & -20 & -20 & 0,76603 & 10230 & 0 \\
\hline 10300 & -29 & -29 & -29 & -29 & 0,75910 & 10271 & 0 \\
\hline
\end{tabular}

Berdasarkan Tabel 4, diketahui bahwa nilai rata-rata selisih terbesar tersebut sama dengan analisis pengujian sebelumnya dengan media cairan yang sama, yaitu $29 \mathrm{~mL}$ pada titik $10300 \mathrm{~mL}$. Rata-rata volume terukur yang dihasilkan kemudian dimuat dalam grafik yang tertera pada Gambar 7.

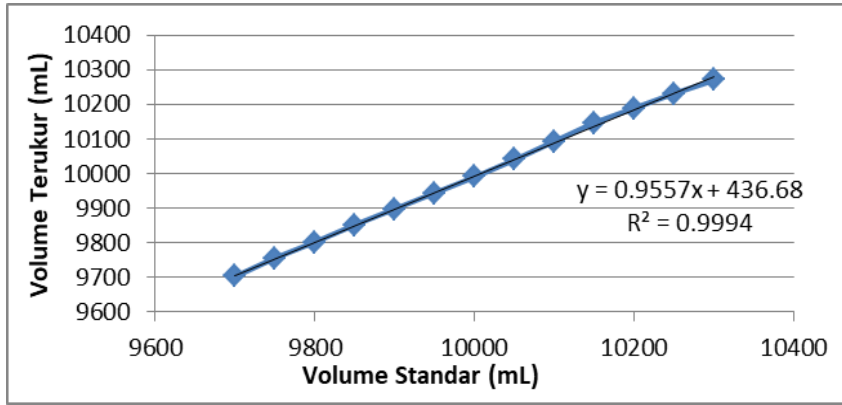

Gambar 7. Grafik Linearitas Hubungan Antara Volume Terukur Berdasarkan Nilai Modus pada LCD dengan Volume Standar pada Air Sirup

Berdasarkan Gambar 7, dapat dilihat bahwa nilai linearitas yang dihasilkan pada analisis pengujian ini sama dengan analisis pengujian yang ditentukan berdasarkan nilai modus pada datalog untuk media air sirup, yakni $\mathrm{R}^{2}=0,9994$.

\section{KESIMPULAN}

Sensor kapasitif dapat bekerja dengan mendeteksi nilai volume cairan berupa tegangan yang diproses mikrokontroler sehingga menghasilkan keluaran berupa $\mathrm{mL}$ yang tertampil pada LCD dan nilai tersebut dapat disimpan pada datalog. Hasil pengujian volume terukur berdasarkan nilai modus pada datalog. Pada media air keran, hasil pengujian volume terukur dengan nilai modus 
pada datalog memiliki linearitas sebesar 0,9992 dan rata-rata selisih terbesar adalah $21 \mathrm{~mL}$. Sedangkan berdasarkan data yang ditentukan oleh nilai modus pada LCD, linearitas yang dimiliki sebesar 0,9991 dan rata-rata selisih terbesar adalah $22 \mathrm{~mL}$. Pada media cairan berbeda (air sirup), volume terukur yang terbaca oleh alat memiliki nilai yang lebih kecil dibandingkan menggunakan media air keran. Hasil pengujian volume terukur dengan nilai modus pada datalog memiliki linearitas yang sama dengan yang ditentukan berdasarkan nilai modus pada LCD, yakni 0,9994. Dan rata-rata selisih terbesar yang dihasilkan juga sama antara kedua analisis tersebut, yakni $29 \mathrm{~mL}$.

\section{DAFTAR PUSTAKA}

[1] Keputusan Direktur Jenderal Perdagangan Dalam Negeri. 2010. "Syarat Teknis Bejana Ukur". Nomor 23/PDN/KEP/3/2010.

[2] Siswoyo, H. 2015. "Perbandingkan Hasil Pengujian Bejana Ukur 20 L dengan Metode Gravimetri dan Volumetri”. Tugas Akhir. Sekolah Vokasi. Universitas Gadjah Mada. Yogyakarta.

[3] Hendrawan, M. 2018. “Analisis Peletakkan Imbuh terhadap Pengujian Bejana Ukur Standar dengan Metode Borda Menggunakan Neraca". Tugas Akhir. Sekolah Vokasi. Universitas Gadjah Mada. Yogyakarta.

[4] Citra, A.K. 2018. "Analisis Kepekaan terhadap Pengujian Bejana ukur Standar Metode Volumetri”. Tugas Akhir. Sekolah Vokasi. Universitas Gadjah Mada. Yogyakarta.

[5] Krisnawan, R.F.W. 2018. "Pengaruh Jumlah Penakaran pada Pengujian Bejana Ukur 20 L Metode Volumetrik Menggunakan Labu Ukur Standar”. Tugas Akhir. Sekolah Vokasi. Universitas Gadjah Mada. Yogyakarta.

[6] Rohsyiyah, E. 2018. “Analisis Hasil Uji Bejana Ukur Volume 5 Liter Menggunakan Metode Gravimetri Direct Weighing dan Double Substitution". Tugas Akhir. Sekolah Vokasi. Universitas Gadjah Mada. Yogyakarta.

[7] Rohmah, A.N. 2019. “Analisis Pengaruh Perbedaan Waktu Tetes terhadap Hasil Pengujian Bejana Ukur 2 Liter”. Tugas Akhir. Sekolah Vokasi. Universitas Gadjah Mada. Yogyakarta.

[8] Zahrotin, E. dan Endarko. 2014. "Rancang Bangun Sensor Kapasitif untuk Level Air". Jurnal Sains dan Seni POMTIS 2. 1, 1-6.

[9] Purcell, E.M. (1985). Electricity and Magnetizm 2 edition. New York: Mc Graw-Hill.

[10] Mustain, A.V.F. 2017. "Pengaruh Konsentrasi Larutan Sukrosa Terhadap Nilai Konstanta Dielektrik Menggunakan Sensor Kapasitor". Skripsi. Fakultas Matematika dan Ilmu Pengetahuan Alam. Universitas Jember. Jember.

[11] Jia, N. 2012. "ADI Capacitance-to-Digital Converter Technology in Healthcare Applications". AnalogDialogue 46.

[12] Wei, Q. Kim M.J. dan Lee, J.H. 2018. "Development of Capacitive Sensor for Automatically Measuring Tumbler Water Level with FEA Simulation". Technology and Health Care 26. 491-500. 
[13] Setyawan, S. 2006. "Pengaruh Variasi Penambahan Tembaga $(\mathrm{Cu})$ dan Jenis Cetakan pada Proses Pengecoran terhadap Tingkat Kekerasan Paduan Aluminium Silikon (Al-Si)”. Skripsi. Fakultas Keguruan dan Ilmu Pendidikan. Universitas Sebelas Maret. Surakarta.

[14] Dita, M.F. dan Widodo, B. 2013. "Karakteristik Aliran Panas dalam Logam Penghantar Listrik". Jurnal Teknik POMITS 2. 1.

[15] Kristanto, Y.B. dan Alaydrus, M. 2012. "Perancangan Kabel Telepon Udara UK.100 x 2 x $0.6 \mathrm{~mm}$ di PT. SUCACO Tbk. dengan Menentukan Diameter Isolasi Sesuai STEL K-0012003 Versi 2.1" Jurnal Teknik Elektro Universitas Mercu Buana 3. 1.

[16] Emsley, J. (2003) Nature's Building Blocks: an A-Z Guide to the Elements. Oxford: Oxford University Press.

[17] Arduino. 2020. Arduino Nano. store.arduino.cc/usa/arduino-nano. diakses pada tanggal 29 Desember 2019.

[18] Alex. 2019. Interface Kapasitif kelembaban tanah Sensor with Arduino. https://how2electronics.com/interface-capacitive-soil-moisture-sensor-with-arduino/. diakses pada tanggal 29 Januari 2020.

[19] DFRobot. 2020. Kapasitif kelembaban tanah Sensor SKU SEN0193. https://wiki.dfrobot.com/Capacitive_Soil_Moisture_Sensor_SKU_SEN0193. diakses pada tanggal 29 Januari 2020.

[20] Alam. 2019. Interface Kapasitif kelembaban tanah Sensor with Arduino. https://how2electronics.com/interface-capacitive-soil-moisture-sensor-with-arduino/. diakses pada tanggal 01 Februari 2020.

[21] Aliyanto, A.N., Saleh, M., dan Hartoyo, A. 2018. "Perancangan Sistem Timbangan Digital Berbasis Arduino Mega 2560”. Jurnal Teknik Elektro Universitas Tanjungpura 2. 1.

[22] Mybotic. 2017. Micro SD Kartu Tutorial. https://www.instructables. com/id/Micro-SDKartu-Tutorial. diakses pada tanggal 02 Januari 2020.

[23] Pranoto, N. 2017. "Prototipe Sistem Presensi Kelas Berbasis RFID dan Micro SD”. Skripsi. Fakultas Teknik. Universitas Muhammadiyah Surakarta. Surakarta.

[24] Setiawan, D.A. 2019. "Prototype Home Security Sistem dengan Autentifikasi KTP-EL". Proyek Akhir. Teknik Elektronika. Universitas Negeri Yogyakarta. Yogyakarta.

[25] Rohmanu, A. dan Widiyanto, D. 2018. "Sistem Sensor Jarak Aman pada Mobil Berbasis Mikrokontroler Arduino ATMEGA328”. Jurnal Informatika SIMANTIK 3. 1.

[26] Supriyono, Selo, dan Andrasto.T. 2011. "Pemantau Temperatur dan Kelembaban pada Rumah Kaca Berbasis Mikrokontroler ATMega8535”. Jurnal Teknik Elektro 3. 2.

[27] Integrated. M. (2015). DS3231 Extremely Accurate I2C-Integrated RTC/TCXO/Crystal. San Jose: Maxim Integrated Products.

[28] Components101. 2018. DS3231 RTC Module. https://components101.com/modules/ds3231rtc-module-pinout-circuit-datasheet. diakses pada tanggal 29 Januari 2020. 
[29] Rozaq, I.A., et al. 2019. "Karakterisasi Sensor Salinitas Menggunakan Arduino Uno, Prosiding Seminar Nasional Multi Disiplin dan Call for Papers UNISBANK (SENDI_U)". 81-83 